\title{
Financial blow slows wind-power projects
}

Boston. Prospects for the development of wind power as a major energy source received a setback at the end of last month when Kenetech Windpower, Inc., the largest developer of 'wind farms' in the United States, filed for bankruptcy protection under Chapter 11 of the US bankruptcy code.

The move jeopardizes some large windpower projects that the company, based in San Francisco, California, was pursuing in California, Maine, Oregon, Washington and Wyoming. Kenetech has not yet announced whether it intends to liquidate all of its assets or reorganize. It is trying to find other developers to take over these projects, which make up about half of the large wind installations planned in the United States.

"It will be difficult for them to find buyers in the current energy market," says Daniel Sosland, an attorney with the Conservation Law Foundation, one of four groups that obtained environmental concessions from Kenetech during negotiations over plans for a proposed wind farm in northern Maine.

Sosland says that the drop in electricity prices over the past five years has been the "single largest factor" contributing to Kenetech's demise. But several other factors played a role, he says, including mechanical problems with the company's wind turbines and a series of lawsuits over warranty claims and other issues.

According to Randall Swisher, executive director of the American Wind Energy Association, an industry trade group, part of the blame rests with inconsistent government policies. He argues that Kenetech may have lost half a billion dollars worth of business because of a decision by the Federal Energy Regulatory Commission in 1995 which struck down an agreement with the state of California that had been five years in the making. Swisher cites other decisions as examples of shortsighted policies, including a recent vote by Republicans in the House of Representatives to eliminate tax incentives for users of wind-energy systems.

But Swisher still maintains Kenetech's failure was "the failure of a single company and not of the domestic wind-power industry in general". Sosland agrees up to a point, although he acknowledges that US wind companies have lost their lead in this field to European companies.

Moreover, the level of private and public investment in such technology in the United States is falling, a trend that he and other clean-power advocates consider alarming. "At some point, the current energy glut will dry up," Sosland argues. "If we let the renewable energy industry collapse in the meantime, it won't be around when we need it.”

Steve Nadis

\section{IMAGE UNAVAILABLE FOR COPYRIGHT REASONS}

An ill wind: falling electricity prices have added to Kenetech Windpower's woes.

\section{Quick launch urged for Cluster 'spare'}

Munich. The scientific advisory committee of the European Space Agency (ESA) proposed last week that the spare unit of the four-satellite Cluster mission should be prepared for launch. The original mission was destroyed when the first qualification flight of ESA's Ariane-5 launcher failed earlier this month (see Nature 381, 541; 1996),

But a vote on the proposals was deferred by the Science Programme Committee, which comprises delegates from ESA's 14 member states, and to which the advisory committee reports, as France wants the whole mission to be relaunched. A final decision on the next step for Cluster will be

\section{Europe narrows patent gap with America}

Munich. The number of patent applications filed last year by European countries at the European Patent Office (EPO) in Munich increased significantly faster, at 8.1 per cent more than in 1994 , than those filed by the United States, which increased by 5.3 per cent. Applications from Japan fell for the first time, by more than one per cent.

Europe's innovative push - primarily from Germany and France - was largely responsible for the 5.5 per cent increase in patent applications filed through the EPO. Figures for the first half of this year indicate the trend is accelerating.

But Ingo Kober, the president of the EPO, warned in presenting the organization's 1995 annual report last week that although the gap with the United States appears to be narrowing, Europe still has a lot of catching up to do. In 1995 . applications from the United States accounted for 29 per cent of the total.

The number of applications in medical and veterinary technologies rose by 7 per cent during 1994. But the highest rate of increase was in patents in computing (11.3 per cent) and electronic communication technologies (12.5 per cent), this time predominantly because of increased applications from the United States and Britain.

Kober repeated a promise to use the surplus accumulated by the EPO, now over DM176 million (US\$276 million), to cut the high costs of patent applications. This cost has been widely criticized as discouraging innovation in Europe (see Nature 375,$270 ; 1995)$. Kober says that the EPO is a service organization, and should not be generating such a high surplus. taken next week.

The Space Science Advisory Committee (SSAC) argues that the spare unit could be reassembled and equipped with instruments at a relatively low cost - ECU30 million (US\$37 million) - which would be within the ESA science programme's contingency funds. This would mean that its costs would not eat into the budget of the programme's other tightly planned missions.

It would also mean that ESA would be able to fulfil international commitments. The possibility of three-dimensional analysis of the electric and magnetic environment of the Earth as it interacts with the solar wind, carried out by the four satellites flying in formation, would be lost.

But the launch of a single unit into the planned orbit - the so-called polar cusps where solar particles can enter the magnetosphere - would at least mean that ESA could maintain its commitment to the wider global terrestrial physics programme, the Interagency Solar Terrestrial Programme, a series of coordinated missions that take measurements in different orbits.

This plan should be implemented immediately, says SSAC, before research and operational teams are broken up. Quick development of the single unit would allow launch on a further Ariane-5 qualification flight, probably next summer.

But France, which had several instruments on Cluster, wants ESA to look more closely at the possibility of relaunching the whole mission, thus saving its original scientific aims - although almost certainly disrupting other space science missions - at a cost of around ECU300 million.

Alison Abbott 